\title{
Profile of reading difficulties in children with attention deficit hyperactivity disorder: a literature review
}

Erica Moraes Silva de Paula(1) Ana Luiza Navas ${ }^{(1)}$

(1) Faculdade de Ciências Médicas da Santa Casa de São Paulo, São Paulo, São Paulo, Brasil.

Conflict of interests: Nonexistent

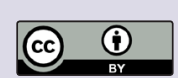

Received on: April 24, 2018

Accepted on: September 11, 2018

Corresponding address:

Ana Luiza Navas

Rua Cesário Motta Jr. 61, 10 . andar,

Vila Buarque

CEP: 02201-020 - São Paulo, São Paulo, Brasil

E-mail: analunavas@gmail.com

\section{ABSTRACT}

Purpose: to characterize the reading alterations in individuals with attention deficit hyperactivity disorder.

Methods: PubMed and SciELO platforms from 2006 to 2016 with the keywords "reading" and "attention deficit hyperactivity disorder", with their equivalents in Portuguese, were searched.

Results: seven hundred ninety articles were found in the two databases, of which 119 were relevant. After a full reading, twenty five articles were selected for the analysis, according to relevance and other exclusion/inclusion criteria. In 21 of the studies, individuals with attention deficit hyperactivity disorder presented worse performance in reading, as compared with their peers. Of these, 14 studies identified a delay in some skills that are important for reading: processing speed, reading accuracy, phonological awareness, comprehension and/or orthographic processing.

Conclusion: these results corroborate other studies that have verified the presence of a deficit in academic performance, especially in reading skills, in individuals with attention deficit hyperactivity disorder, that may persist in their adulthood.

Keywords: Reading; Attention deficit hyperactivity disorder; Language 


\section{INTRODUCTION}

Attention deficit hyperactivity disorder (ADHD) is a neurodevelopmental disorder characterized by a persistent pattern of inattention, hyperactivity and impulsivity, not expected in typical development, according to the Diagnostic and Statistical Manual of Mental Disorders (DSM-V) 1 .

Different studies, especially with twins, have shown the presence of genetic inheritance in $A D H D^{2}$. Genetic vulnerability to ADHD appears to be mediated by several small-effect genes, but further studies are needed to precisely identify what these effects are, as well as which phenotypes are specific for subtypes and comorbidities of the disorder ${ }^{3}$.

In respect of the biological aspects, some studies have shown that individuals with ADHD present a possible failure in the activation of the striated nucleus, a brain region with a high concentration of dopamine linked to the reward system. In one study, individuals in a control group had striated nucleus activation and dopamine release as soon as they were told about a reward, while individuals with ADHD had the release only after actually receiving it. This delay in reward circuit response may explain the inattention and impulsivity present in individuals with $\mathrm{ADHD}^{4}$. These characteristics persist in adolescence and adulthood, but may be less pronounced ${ }^{5}$.

ADHD may be accompanied by comorbidities, the most frequent being written language disorders that appear in $14 \%$ of children with ADHD. These findings highlight the importance of the attentional factor in relation to the domain of the language, and emphasize the importance of attention for any type of learning.

In many cases of ADHD, the family and school only refer children to specialists when they are already behind in terms of school performance. Therefore, it is important to look out for reading and writing difficulties that may be due to the inattention, impulsivity or hyperactivity that are associated with ADHD. As the symptomatology of ADHD can affect several areas that impair school performance, it is necessary to identify how this can have an impact on the specific skills necessary for the good development of reading and writing. It is, therefore, important to include both oral and written language assessments to complete the performance profile and assist in the diagnosis of ADHD. This study aimed to identify, through a review of the literature, the reading disorders present in children with $A D H D$ in order to better inform professionals from different areas, as well as to qualify the process of evaluation and intervention for children and adolescents with ADHD. In addition, it was intended to verify the hypothesis that as a result of the attention deficit, there may be decoding errors due to excessive reading guess, reading fluency deficits, which consequently affect reading comprehension.

\section{METHODS}

PubMed and SciELO databases were searched for articles published between 2006 and 2016 in Portuguese or English, using a combination of the terms "leitura" and "Transtorno do Deficit de Atenção e Hiperatividade (TDAH)" and their equivalents in English, "reading" and "attention deficit hyperactivity disorder (ADHD)". The databases were selected for their thematic scope and for including open access articles. The search was performed using the advanced search function in both databases, with items classified by relevance, according to the criteria of the database chosen. The choice to only include articles published in Portuguese and English was based on the idea that any scientific community should have access to articles published in their own language, as well as those published in English, the access language of international science.

\section{Selection criteria}

The selection criteria were complete, original articles, published between the years 2006 and 2016, published in Portuguese or English. General studies on ADHD with specific reading disorders as comorbidities were included. Duplicate articles, articles not relevant to the subject, reviews, genetic studies, studies with illiterate/pre-school subjects, case studies, treatment studies, and surveys containing other comorbidities were excluded. Table 1 shows the excluded articles.

\section{Data analysis}

Initially, the first 100 articles were selected according to relevance in each database. The first inspection for the criteria was based on the reading of the titles and abstracts of articles with open access. All duplicate articles were excluded as well as those that did not meet established selection criteria. The same procedure was done for articles with restricted access. When there was doubt about the exclusion criteria, a second judge analyzed the article. The author and the advisor of this study were considered the judges for the inclusion or exclusion of the articles. Upon completion of the 
collection of the database for analysis, all articles were read completely in order to record all relevant details for further analysis. The studies were organized by journal, year of publication, age of population studied, diagnosis, language spoken, the main purpose of the study, the experimental approach, measures used, and conclusions. For the present study, it focused on the discussion of participants' reading characteristics.

\section{LITERATURE REVIEW}

From the survey of the literature, 790 articles were found (771 in PubMed and 19 in Scielo), of which the 100 most relevant were selected from PubMed and all 19 from Scielo.

After reading the titles and abstracts we selected 34 articles for the complete analysis. A summary of the selection process is shown in Figure 1.

Exclusion and inclusion criteria were used to select the articles. The ones excluded were duplicates or did not fit in the criteria. Review articles or Case reports were also excluded. Table 1 shows the articles excluded.

Examining the geohistorical distribution of the articles, in terms of the year of publication, country of origin and language of the publication, may help to understand the interest in this area of research around the world in recent years. Most of the studies analyzed were published in the last 3 years (2014 to 2016) of the period investigated. Of the 25 articles, 6 (24\%) were published in 2016, 4 (16\%) were published in 2015, $6(24 \%)$ in 2014, $4(16 \%)$ in 2013, 1 in 2012 (4\%), $3(12 \%)$ in 2011 , and 1 (4\%) in 2008. Most of the studies were conducted in the United States of America
(10), followed by Brazil (5), Germany (2), Australia (2), Canada (2), Israel (2), Belgium (1) and Spain (1). Of the 25 articles, 21 (84\%) were published in English and 4 (16\%) in Portuguese.

Figures 2 and 3 show details of each study such as date of publication, authorship, country, goal of the study, sample description, and main findings of the 25 studies analysed ${ }^{6-30}$.

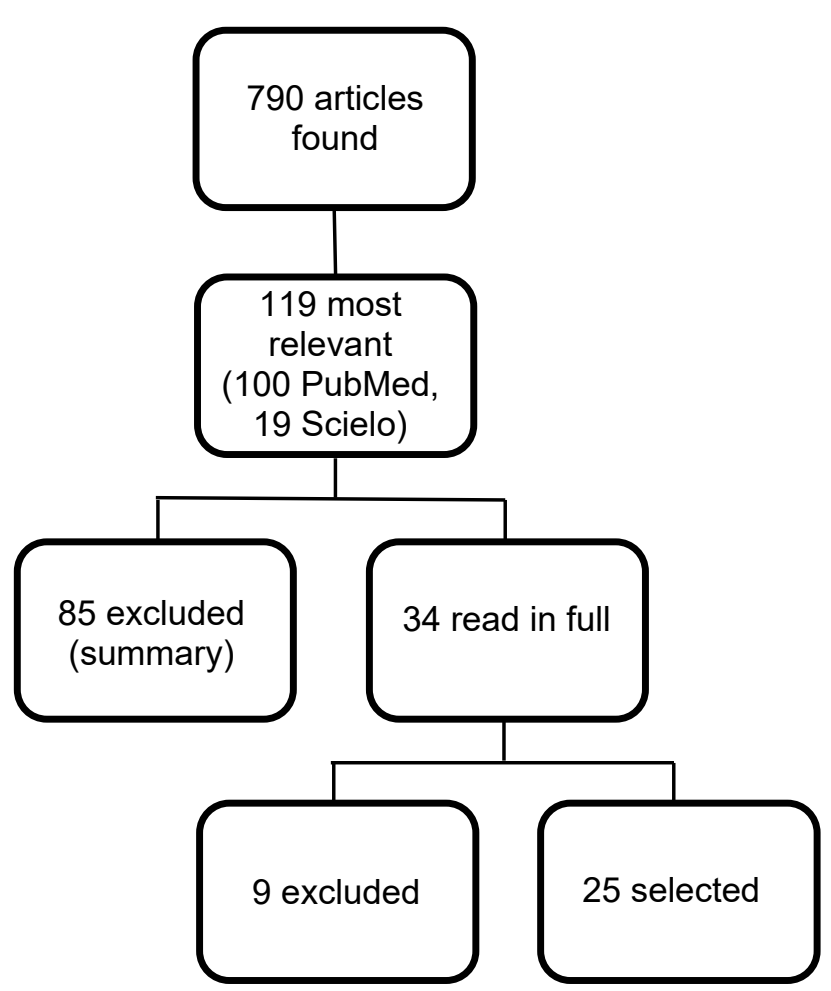

Figure 1. Organization Chart used for the Systematic Review Process

Table 1. Distribution of articles excluded according to the exclusion criterion

\begin{tabular}{cccc}
\hline Category & PubMed & Scielo & Total \\
\hline Restricted access & 2 & 0 & 2 \\
Duplicate & 3 & 1 & 4 \\
Case report & 0 & 1 & 1 \\
Genetics & 8 & 0 & 8 \\
Language & 4 & 2 & 6 \\
Non related with the topic & 48 & 9 & 57 \\
Literature review & 2 & 1 & 3 \\
Other psychiatric/neurologic disorders & 4 & 0 & 4 \\
Preschoolers/iliterates & 2 & 0 & 2 \\
Treatment & 6 & 1 & 7 \\
\hline Total & 79 & 15 & 94 \\
\hline
\end{tabular}




\begin{tabular}{|c|c|c|c|c|c|}
\hline ARTICLE TITLE & YEAR & PERIODIC & COUNTRY & AUTHORS & OBJECTIVE \\
\hline $\begin{array}{l}\text { Academic Achievement in Adults } \\
\text { with a History of Childhood Atten- } \\
\text { tion- Deficit/ Hyperactivity Disor- } \\
\text { der: A Population-Based Prospec- } \\
\text { tive Study }\end{array}$ & 2016 & \begin{tabular}{|c|} 
Journal of \\
developmental and \\
behavioral pediatrics
\end{tabular} & USA & $\begin{array}{c}\text { Voigt, Katusic, } \\
\text { Colligan, Killian, } \\
\text { Weaver, Barbaresi(6) }\end{array}$ & $\begin{array}{l}\text { To describe academic outcomes in adul- } \\
\text { thood among incident cases of childhood } \\
\text { ADHD versus non-ADHD referents from a } \\
\text { population-based cohort. }\end{array}$ \\
\hline $\begin{array}{l}\text { Academic and Social Functioning } \\
\text { Associated with Attention-Deficit/ } \\
\text { Hyperactivity Disorder: Latent } \\
\text { Class Analyzes of Trajectories } \\
\text { from Kindergarten to Fifth Grade }\end{array}$ & 2016 & $\begin{array}{l}\text { Journal of Abnormal } \\
\text { Child Psychology }\end{array}$ & USA & $\begin{array}{l}\text { DuPaul,Morgan, } \\
\text { Farkas Hillemeier, } \\
\text { Maczuga }\end{array}$ & $\begin{array}{l}\text { To analyze the academic and social per- } \\
\text { formance trajectory in children with ADHD } \\
\text { from kindergarten through 5th grade }\end{array}$ \\
\hline $\begin{array}{l}\text { Attention-Deficit/Hyperactivity } \\
\text { Disorder severity, diagnosis, \& } \\
\text { later academic achievement in a } \\
\text { national sample }\end{array}$ & 2016 & $\begin{array}{c}\text { Journal Social } \\
\text { Science Research }\end{array}$ & USA & Owens, Jackson (27) & $\begin{array}{l}\text { To compare diagnosed and undiagnosed } \\
\text { children who are cognitively, behaviorally, } \\
\text { and demographically similar, as they were } \\
\text { followed up from kindergarten through 8th } \\
\text { grade. }\end{array}$ \\
\hline $\begin{array}{l}\text { Online inferential and textual } \\
\text { processing by adolescents with } \\
\text { Attention-Deficit/Hyperactivity } \\
\text { Disorder during reading compre- } \\
\text { hension: evidence from a probing } \\
\text { method }\end{array}$ & 2016 & $\begin{array}{l}\text { Journal of Clinical } \\
\text { and Experimental } \\
\text { Neuropsychology }\end{array}$ & ISRAEL & Yeari, Schiff ${ }^{(20)}$ & $\begin{array}{l}\text { To examine the spontaneous, immediate ac- } \\
\text { tivation and/or suppression of forward-pre- } \\
\text { dictive inferences, backward-explanatory } \\
\text { inferences, and inference-evoking textual } \\
\text { information, as they occur online during re- } \\
\text { ading comprehension by adolescents }\end{array}$ \\
\hline $\begin{array}{l}\text { Rapid naming in Brazilian stu- } \\
\text { dents with Dyslexia and Attention } \\
\text { Deficit Hyperactivity Disorder }\end{array}$ & 2016 & $\begin{array}{l}\text { Journal Frontiers in } \\
\text { Psychology }\end{array}$ & Brazil & $\begin{array}{l}\text { Alves, Siqueira, } \\
\text { Ferreira, Alves, } \\
\text { Bicalho, Celeste }^{(17)}\end{array}$ & $\begin{array}{l}\text { To assess the rapid automatized naming } \\
\text { (RAN) performance in children with reading } \\
\text { disorder and attention deficit hyperactivity } \\
\text { disorder (ADHD) compared with their nor- } \\
\text { mal peers. }\end{array}$ \\
\hline $\begin{array}{l}\text { Reading comprehension in boys } \\
\text { with ADHD: the mediating roles } \\
\text { of working memory and ortho- } \\
\text { graphic conversion }\end{array}$ & 2016 & $\begin{array}{c}\text { Journal of Abnormal } \\
\text { Child Psychology }\end{array}$ & USA & $\begin{array}{l}\text { Friedman, Rapport, } \\
\text { Raiker, Orban, } \\
\text { Eckrich }^{(16)}\end{array}$ & $\begin{array}{l}\text { To examine two cognitive aspects of pro- } \\
\text { cesses involved in reading and comprehen- } \\
\text { sion abilities - (a) working memory and } \\
\text { orthographic conversion (phonological text } \\
\text { conversion) - in order to elucidate their inte- } \\
\text { ractive contribution to reading comprehen- } \\
\text { sion differences. }\end{array}$ \\
\hline $\begin{array}{l}\text { Naming speed of adolescents and } \\
\text { young adults with Attention Deficit } \\
\text { Hyperactivity Disorder: differenc- } \\
\text { es in alphanumeric versus color/ } \\
\text { object naming }\end{array}$ & 2015 & $\begin{array}{l}\text { Archives of Clinical } \\
\text { Neuropsychology }\end{array}$ & USA & Whipple, Nelson ${ }^{(7)}$ & $\begin{array}{l}\text { To investigate the performance in adoles- } \\
\text { cents and young adults with ADHD, Reading } \\
\text { Disorder (RD), and ADHD/RD on measures } \\
\text { of alphanumeric and nonalphanumeric na- } \\
\text { ming speed and the relationship between } \\
\text { naming speed and academic achievement. } \\
\text { Mood disorders included. }\end{array}$ \\
\hline $\begin{array}{l}\text { Performance-based tests versus } \\
\text { behavioral ratings in the assess- } \\
\text { ment of executive functioning in } \\
\text { preschoolers: associations with } \\
\text { ADHD symptoms and reading } \\
\text { achievement }\end{array}$ & 2015 & $\begin{array}{l}\text { Journal Frontiers in } \\
\text { Psychology }\end{array}$ & SPAIN & $\begin{array}{l}\text { Miranda, Colomer, } \\
\text { Mercader, Fernández, } \\
\text { Presentación }{ }^{(26)}\end{array}$ & $\begin{array}{l}\text { The first objective is to analyze the rela- } \\
\text { tionship between preschoolers' perfor- } \\
\text { mance on tests of Working Memory and } \\
\text { Inhibition and parents' and teachers' ratings } \\
\text { of these executive functions using the Beha- } \\
\text { vior Rating Inventory of Executive Function. } \\
\text { The second objective consisted of studying } \\
\text { the predictive value of the different EF me- } \\
\text { asures (performance-based test and rating } \\
\text { scales) on ADHD symptoms and on indica- } \\
\text { tors of word reading performance. }\end{array}$ \\
\hline $\begin{array}{l}\text { Reading comprehension in ado- } \\
\text { lescents with ADHD: Exploring the } \\
\text { poor comprehender profile and in- } \\
\text { dividual differences in vocabulary } \\
\text { and executive functions }\end{array}$ & 2015 & $\begin{array}{l}\text { Journal Research } \\
\text { in Developmental } \\
\text { Disabilities }\end{array}$ & CANADA & $\begin{array}{l}\text { Martinussen, } \\
\text { Mackenzie }\end{array}$ & $\begin{array}{l}\text { To determine whether youth with and wi- } \\
\text { thout ADHD matched in word reading and } \\
\text { reading comprehension proficiency. The } \\
\text { second objective was to determine whether } \\
\text { good and poor comprehenders within the } \\
\text { ADHD subgroup differed from each other on } \\
\text { language and academic achievement mea- } \\
\text { sures. The third objective was to examine } \\
\text { the effect of ADHD symptoms on word re- } \\
\text { cognition or oral vocabulary knowledge and } \\
\text { reading comprehension performance. }\end{array}$ \\
\hline
\end{tabular}




\begin{tabular}{|c|c|c|c|c|c|}
\hline $\begin{array}{l}\text { Visual processing in reading } \\
\text { disorders and attention-deficit/ } \\
\text { hyperactivity disorder and its con- } \\
\text { tribution to basic reading ability }\end{array}$ & 2015 & $\begin{array}{c}\text { Journal Frontiers in } \\
\text { Psychology }\end{array}$ & USA & $\begin{array}{l}\text { Kibby, Dyer, Vadnais, } \\
\text { Jagger, Casher, } \\
\text { Stacy }{ }^{(24)}\end{array}$ & $\begin{array}{l}\text { To investigate visual processing in reading } \\
\text { disorders and attention deficit hyperactivity } \\
\text { disorder/hyperactivity and its contribution to } \\
\text { the basic reading ability }\end{array}$ \\
\hline $\begin{array}{l}\text { A longitudinal study of neuro- } \\
\text { psychological functioning and } \\
\text { academic achievement in children } \\
\text { with and without signs of atten- } \\
\text { tion deficit/hyperactivity disorder }\end{array}$ & 2014 & $\begin{array}{l}\text { Journal of Clinical } \\
\text { and Experimental } \\
\text { Neuropsychology }\end{array}$ & USA & $\begin{array}{l}\text { Rennie, Beebe- } \\
\text { Frankenberger, } \\
\text { Swanson }{ }^{(28)}\end{array}$ & $\begin{array}{l}\text { To examine the relationship between ADHD } \\
\text { and academic performance in children in a } \\
\text { developmental context. }\end{array}$ \\
\hline $\begin{array}{l}\text { Functional status in children with } \\
\text { ADHD at age 6-8: a controlled } \\
\text { community study }\end{array}$ & 2014 & Journal Pediatrics & AUSTRALIA & Efron et al. ${ }^{(23)}$ & $\begin{array}{l}\text { To examine the functional status (mental } \\
\text { health, performance, peer problems) of a } \\
\text { community-based sample of ADHD and } \\
\text { non-ADHD children, and to investigate gen- } \\
\text { der and subtype differences. }\end{array}$ \\
\hline $\begin{array}{l}\text { Language problems in children } \\
\text { with ADHD: a community-based } \\
\text { Study }\end{array}$ & 2014 & Journal Pediatrics & AUSTRALIA & Sciberras et al.(15) & $\begin{array}{l}\text { To examine the prevalence of language pro- } \\
\text { blems in children with ADHD compared to } \\
\text { a control group, and to check the impact of } \\
\text { language problems on the social and aca- } \\
\text { demic development of children with ADHD. }\end{array}$ \\
\hline $\begin{array}{l}\text { Nonword reading and Stroop in- } \\
\text { terference: What differentiates } \\
\text { Attention-Deficit/Hyperactivity } \\
\text { Disorder and Reading Disability? }\end{array}$ & 2014 & $\begin{array}{l}\text { J. of Clinical and } \\
\text { Experimental } \\
\text { Neuropsychology }\end{array}$ & GERMANY & Stubenrauch et al.(14) & $\begin{array}{l}\text { To investigate the differences in reading be- } \\
\text { tween individuals with ADHD and individu- } \\
\text { als with reading disability. }\end{array}$ \\
\hline $\begin{array}{l}\text { Reaction time variability associ- } \\
\text { ated with reading skills in poor } \\
\text { readers with ADHD }\end{array}$ & 2014 & $\begin{array}{c}\text { J. of the } \\
\text { International } \\
\text { Neuropsychological } \\
\text { Society }\end{array}$ & USA & $\begin{array}{l}\text { Tamm, Epstein, } \\
\text { Denton, Vaughn, } \\
\text { Peugh, Willcutt(29) }\end{array}$ & $\begin{array}{l}\text { To check for associations between neurop- } \\
\text { sychological functioning and other reading } \\
\text { skills (fluency, comprehension) among } \\
\text { children with comorbid ADHD and reading } \\
\text { disorder. }\end{array}$ \\
\hline $\begin{array}{l}\text { The influence of working memory } \\
\text { load on response inhibition in } \\
\text { children with attention deficit/ } \\
\text { hyperactivity disorder or reading } \\
\text { disorder }\end{array}$ & 2014 & $\begin{array}{l}\text { Journal of Clinical } \\
\text { and Experimental } \\
\text { Neuropsychology }\end{array}$ & BELGIUM & $\begin{array}{l}\text { Van de Voorde, } \\
\text { Roeyers, Verté, } \\
\text { Wiersema }{ }^{(30)}\end{array}$ & $\begin{array}{l}\text { To examine the relationship between res- } \\
\text { ponse inhibition and working memory in } \\
8-12 \text {-year-old children with attention-de- } \\
\text { ficit/hyperactivity disorder and/or reading } \\
\text { disorder }\end{array}$ \\
\hline $\begin{array}{l}\text { Children with ADHD Symptoms } \\
\text { have a higher risk for reading, } \\
\text { spelling and math difficulties in } \\
\text { the GINIplus and LISAplus cohort } \\
\text { studies }\end{array}$ & 2013 & Journal PLOS ONE & GERMANY & Czamara et al. ${ }^{(8)}$ & $\begin{array}{l}\text { To investigated the comorbidity between } \\
\text { ADHD symptoms and reading/spelling and } \\
\text { math difficulties in two population-based } \\
\text { birth cohort studies. }\end{array}$ \\
\hline $\begin{array}{l}\text { Desempenho de escolares com } \\
\text { Transtorno de Déficit de Atenção } \\
\text { e Hiperatividade (TDAH) em tare- } \\
\text { fas metalinguísticas e de leitura }\end{array}$ & 2013 & Revista CEFAC & BRAZIL & $\begin{array}{l}\text { Cunha, Silva, } \\
\text { Lourencetti, Padula, } \\
\text { Capellini }^{(13)}\end{array}$ & $\begin{array}{l}\text { To compare and characterize the perfor- } \\
\text { mance of schoolchildren with Attention } \\
\text { Deficit Hyperactivity Disorder (ADHD) in } \\
\text { metalinguistic and reading tasks with scho- } \\
\text { olchildren without behavioral disorders and/ } \\
\text { or learning disabilities. }\end{array}$ \\
\hline $\begin{array}{l}\text { Performance lapses in children } \\
\text { with Attention-Deficit/Hyperactiv- } \\
\text { ity Disorder contribute to poor } \\
\text { reading fluency }\end{array}$ & 2013 & $\begin{array}{l}\text { Journal archives } \\
\text { of clinical } \\
\text { neuropsychology. }\end{array}$ & USA & $\begin{array}{c}\text { Jacobson, Ryan, } \\
\text { Denckla, Mostofsky, } \\
\text { Mark }^{(12)}\end{array}$ & $\begin{array}{l}\text { To examine response times and response } \\
\text { variability in normal and ADHD children by } \\
\text { means of a simple reaction time (SRT) task. } \\
\text { Children with ADHD are expected to have } \\
\text { longer reaction times and greater reaction } \\
\text { time variability, which could be associated } \\
\text { with reading fluency. }\end{array}$ \\
\hline $\begin{array}{l}\text { The role of sustained attention } \\
\text { and display medium in reading } \\
\text { comprehension among adoles- } \\
\text { cents with ADHD and without it }\end{array}$ & 2013 & $\begin{array}{l}\text { Journal Research } \\
\text { in Developmental } \\
\text { Disabilities }\end{array}$ & ISRAEL & Stern, Shalev ${ }^{(19)}$ & $\begin{array}{l}\text { To investigate the relation between sustai- } \\
\text { ned attention and reading comprehension } \\
\text { among adolescents with and without ADHD. } \\
\text { Another goal was to examine the impact of } \\
\text { two manipulations of the text on the effi- } \\
\text { ciency of reading comprehension: spacing } \\
\text { (standard- versus double-spacing) and type } \\
\text { of presentation (computer screen versus } \\
\text { hard copy). }\end{array}$ \\
\hline
\end{tabular}




\begin{tabular}{|c|c|c|c|c|c|}
\hline $\begin{array}{l}\text { Processamento da linguagem no } \\
\text { Transtorno de Déficit de Atenção } \\
\text { e Hiperatividade (TDAH) }\end{array}$ & 2012 & D.E.L.T.A & BRAZIL & $\begin{array}{l}\text { Albuquerque, Maia, } \\
\text { França, Mattos, } \\
\text { Pastura(11) }^{(11)}\end{array}$ & $\begin{array}{l}\text { To investigate the primary language com- } \\
\text { ponents of Attention Deficit Hyperactivity } \\
\text { Disorder (ADHD) in order to contribute to a } \\
\text { more accurate characterization of the rea- } \\
\text { ding in the patients having this disorder }\end{array}$ \\
\hline $\begin{array}{l}\text { A multiple deficit model of Read- } \\
\text { ing Disability and Attention- } \\
\text { Deficit/ Hyperactivity Disorder: } \\
\text { Searching for shared cognitive } \\
\text { deficits }\end{array}$ & 2011 & $\begin{array}{l}\text { Journal of Child } \\
\text { Psychology and } \\
\text { Psychiatry }\end{array}$ & USA & McGrath et al.(21) & $\begin{array}{l}\text { To test a multiple cognitive deficit model } \\
\text { of reading disability (RD), attention-deficit/ } \\
\text { hyperactivity disorder (ADHD), and their co- } \\
\text { morbidity. }\end{array}$ \\
\hline $\begin{array}{l}\text { Desempenho cognitivo-linguísti- } \\
\text { co e em leitura de escolares com } \\
\text { Transtorno de Déficit de Atenção } \\
\text { e Hiperatividade (TDAH) }\end{array}$ & 2011 & $\begin{array}{l}\text { Revista brasileira } \\
\text { de crescimento } \\
\text { desenvolvimento } \\
\text { humano }\end{array}$ & BRAZIL & $\begin{array}{l}\text { Silva, Cunha, } \\
\text { Capellini(10) }\end{array}$ & $\begin{array}{l}\text { To compare the cognitive-linguistic and re- } \\
\text { ading performance in students with Atten- } \\
\text { tion Deficit and Hyperactivity Disorder and } \\
\text { students without behavioral and/or learning } \\
\text { disorders. }\end{array}$ \\
\hline $\begin{array}{l}\text { Inattention, working memory, and } \\
\text { academic achievement in adoles- } \\
\text { cents referred for attention deficit/ } \\
\text { hyperactivity disorder (ADHD) }\end{array}$ & 2011 & $\begin{array}{c}\text { Journal Child } \\
\text { Neuropsychology }\end{array}$ & CANADA & $\begin{array}{c}\text { Rogers, Toplak, } \\
\text { Weiss, Tannock }{ }^{(18)}\end{array}$ & $\begin{array}{l}\text { To investigate the role of inattention and } \\
\text { working memory in predicting academic } \\
\text { achievement. Path analysis was used to } \\
\text { examine whether auditory-verbal and visual- } \\
\text {-spatial working memory would mediate the } \\
\text { relationships between classroom inattention } \\
\text { symptoms and achievement outcomes. }\end{array}$ \\
\hline $\begin{array}{l}\text { Comparação do desempenho em } \\
\text { leitura de palavras de crianças } \\
\text { com e sem Transtorno de Dé- } \\
\text { ficit de Atenção e Hiperatividade } \\
\text { (TDAH) }\end{array}$ & 2008 & Revista CEFAC & BRAZIL & Lobo, Lima ${ }^{(9)}$ & $\begin{array}{l}\text { To determine whether there are qualitati- } \\
\text { ve and/or quantitative differences in silent } \\
\text { reading at the level of decoding words in } \\
\text { isolation; to identify the aspects that could } \\
\text { justify these differences, if any; to characte- } \\
\text { rize changes in the silent reading of words } \\
\text { in isolation that could be specific to ADHD } \\
\text { children; and to determine the possible re- } \\
\text { lations between the findings and attention } \\
\text { deficits. }\end{array}$ \\
\hline
\end{tabular}

Figure 2. Identification and description of the selected articles, in chronological order of publication 
ARTICLE

Academic Achievement in Adults with a History of Childhood Attention-Deficit/Hyperactivity Disorder: A Population-Based Prospective Study (6)

Academic and Social Functioning 590 children diagnosed with ADHD (referAssociated with Attention-Deficit/ red by parents), early childhood education, Hyperactivity Disorder: Latent Class in the 1st, 3rd or 5th grades. 580 comAnalyses of Trajectories from Kindergarten to Fifth Grade (22)

Attention-Deficit/Hyperactivity Disorder severity, diagnosis, \& later gh 8th grade), of whom 350 were diagnoacademic achievement in a national sed with ADHD. sample ${ }^{(27)}$

Online inferential and textual process- 46 students with ADHD (medicated or not) ing by adolescents with Attention- and 45 controls, without ADHD or other Deficit/Hyperactivity Disorder during neurological disease.

reading comprehension: evidence from a probing method ${ }^{(20)}$

Rapid naming in Brazilian students 70 schoolchildren between 8 and 11 years with Dyslexia and Attention Deficit old: 16 with ADHD, 14 with dyslexia, 40 Hyperactivity Disorder ${ }^{(17)}$ with no history of developmental disorder. All of them were from public schools.

Reading comprehension in boys 61 boys aged 8 to 12 years: 31 with ADHD with ADHD: the mediating roles of and 30 without ADHD or other psychologiworking memory and orthographic cal and mental disorders.

Naming speed of adolescents and Schoolchildren aged 17-28 years, 83 with young adults with Attention Deficit ADHD, 71 with RD, 49 with ADHD/RD, Hyperactivity Disorder: differences total 203, over a period of 4 years. Schoin alphanumeric versus color/object olchildren presenting with autism or other naming ${ }^{(7)}$ conversion ${ }^{(16)}$

READING PERFORMANCE OUTCOMES

Subjects with ADHD had below-average performance in all aspects of reading assessed (naming speed and accuracy). Academic performance in individuals with ADHD in childhood was similar to that of either adults with persistent ADHD or who were diagnosed later. Among the groups evaluated, the comorbidity group had the worst performance.

Overall reading ability showed below average results, and remained until 5th grade in most class trajectories. Although the authors administered tests for different reading skills, they did not disclose the results for each skill and each grade.

Children with ADHD-related behaviors (diagnosed or not, comorbid or not) performed worse academically than did children relatively less severely affected by ADHD. Children diagnosed with ADHD and having less severe behaviors differed when compared to their undiagnosed peers, but with ADHD-related symptoms both in reading and in math. Reading abilities and comprehension were assessed; still, the authors did not identify which ability was worse/ better.

Adolescents with ADHD have difficulty generating predictive and explanatory inferences and retaining relevant textual information in working memory during reading, although they are able to answer questions when texts are relatively short. Slow reading speed, decreased inferential comprehension, reduced online textual processing.

Schoolchildren with dyslexia or ADHD take longer to perform rapid naming tasks compared to their peers, hence their reading speed is reduced.

CE (central executive), orthgraphic conversion and reading comprehension showed worse results in the ADHD group than in the control group, which influenced reading comprehension indirectly by means of the functioning of the CE on the orthographic system.

Individuals with ADHD were faster in alphanumerical naming measures compared to RD (reading disorders) and Comorbid ADHD/ RD Groups and, within the group, named letters/digits significantly faster than they did colors/objects. The alphanumerical naming and processing speed scores predicted variation in academic performance scores across groups, while non-alphanumerical naming scores only predicted reading comprehension scores within the ADHD group. Naming letters or digits is better than naming colors or objects. This influences the academic tasks associated with reading fluency and processing.

Performance-based tests versus be- 209 children in the last preschool year, Both assessment scales and performance-based tests were sighavioral ratings in the assessment of their teachers and their families. public nificant predictors of inattention and Hyperactivity/lmpulsiveness executive functioning in preschool- schools (63.3\%); private schools subsiers: associations with ADHD symp- dized by the government $(30.6 \%)$; and toms and reading achievement ${ }^{(26)}$ private schools (5.9\%). behaviors and reading performance measures. However, the BRIEF scale explained why a higher variance percentage was found for ADHD symptoms, while performance-based tests explained reading achievement to a greater degree. The implications of the findings in research and clinical practice are discussed. Different reading aspects were not specified. There was an important relationship between the executive functions and academic performance tests 
ARTICLE comprehender profile and individual arning disorder. differences in vocabulary and executive functions ${ }^{(25)}$ cents with ADHD: Exploring the poor 87 boys aged 13 to 18 years: 45 with a

\section{PARTICIPANTS \\ READING PERFORMANCE OUTCOMES}

Youth with ADHD had significantly lower scores in comparison with a standardized reading comprehension measure. Relative to ADHD individuals with good comprehension, those with ADHD and a poor performance in understanding exhibited weaknesses in expressive vocabulary, mathematical reasoning, written expression, and had more difficulties in terms of their executive function (EF), as reported by their teacher. Expressive vocabulary and word reading represented a unique variation in reading comprehension performance and mediated the relationship between ADHD symptoms and reading comprehension. Therefore, reading comprehension was found to be worse than in the control group; the individuals with the worst expressive vocabulary, reasoning and written expression were also the worst readers.

Visual processing in reading disor- 264 children between 8 and 12 years, 51 ders and attention-deficit/hyperac- with reading disorder (RD), 88 with ADHD, tivity disorder and its contribution to 51 with $\mathrm{ADHD}$ and RD, 74 normal. RD: basic reading ability ${ }^{(24)}$

many have had or had experienced some sort of intervention; ADHD: some were already taking medication. Public or private schools. ADHD schoolchildren with predominant inattention, but with no predominant impulsivity/hyperactivity, were included.

A longitudinal study of neuropsy- 51 participants initially from the 1 st, 2nd chological functioning and academ- or 3rd grades, and then 3rd, 4th and 5th. ic achievement in children with and With signs of $\operatorname{ADHD}(n=17)$ or mild signs without signs of attention deficit/ $(n=34)$.

hyperactivity disorder ${ }^{(28)}$

Functional status in children with Children aged 6 to 8 years were recruited ADHD at age 6-8: a controlled community study ${ }^{(23)}$

at 43 schools in Melbourne. 179 ADHD and 212 non-ADHD children were recruited.

Visual processing may be intact in RD and ADHD when measured by means of discrimination tasks of indeterminate length and visual Short Term Memory, which do not require sequential processing or allow easy labeling. It did not specifically address reading-related aspects in individuals with ADHD compared to the control, but it showed that processing speed was associated with reading fluency.

The results indicate that there is considerable variability in the relation between reading, mathematics and neuropsychological factors. The study did not specifically address reading-related aspects in individuals with $\mathrm{ADHD}$ in comparison to the control.

In the second year of schooling, children with ADHD performed worse than did the controls in all functional domains; a minority of them had been formally diagnosed with ADHD. The ADHD performed worse in reading and mathematics than did their peers, but the authors did not specify which aspects related to reading were actually involved.

Language problems in children with 179 children with ADHD and 212 children ADHD: a community-based Study ${ }^{(15)}$ without ADHD, aged 6 to 8 years.

Both boys and girls with ADHD had high prevalence of language problems, which caused them to have a significantly lower academic performance than the control group. The reading speed of words was reduced in the group with ADHD.

Nonword reading and Stroop inter- 68 boys aged 8 to 12 years: 16 with ADHD, ference: What differentiates Atten- 17 with RD, 18 with both, 17 healthy. They tion-Deficit/Hhyperactivity Disorder were assessed with a 2 (ADHD versus no and Reading Disability? ${ }^{(14)}$

ADHD) $\times 2$ (RD vs. no RD) test. Children with neurological disorders or psychoses were excluded. Those with an IQ below 85 were also excluded.

Reaction time variability associated with reading skills in poor readers with $\mathrm{ADHD}^{(29)}$

65 children with ADHD (combined or pre-
dominantly inattentive), with a standard score of 90 or less in the reading subtest WJ - III; IQ > 70 in KBIT-2 (verbal and non-verbal abilities)

The results show non-word reading deficits, not only reading disorders (RD) deficits, and in children with ADHD to a lesser degree. In addition, RD and non-ADHD were characterized by poor interference control in the Stroop task (naming word colors, but not word reading). These data lead one to question whether single cognitive deficits are specific to ADHD or DR.

Children with ADHD and poor readers performed poorly compared to average time, which interferes with reading, fluency and comprehension. There was no difference specifically in different aspects of reading, but rather only a correlation of these abilities with reaction time/latency variability.

The influence of working memory $\operatorname{ADHD}(n=19)$; reading disorder - RD In the task involving letters, an interaction between ADHD and meload on response inhibition in chil- $(\mathrm{N}=17), \mathrm{ADHD}+\mathrm{RD}(\mathrm{N}=21)$, and condren with attention deficit/hyperac- trol group $(\mathrm{N}=19)$ tivity disorder or reading disorder(30) mory was found. There was found a relationship between inhibition and working memory in the ADHD group, reading disorder group, and in the comorbid group when the demand increased in the same task. Despite this, in the study there was no expressive relation between executive function deficit and the presence of a disorder (ADHD or reading). No specific changes in the reading tasks are cited. 
ARTICLE a higher risk for reading, spelling and math difficulties in the GINIplus and LISAplus cohort studies ${ }^{(8)}$
Children with ADHD Symptoms have

PARTICIPANTS

READING PERFORMANCE OUTCOMES

LISAplus (the influence of lifestyle factors on immune system development and allergies in East and West Germany plus the influences of environment and genetics): 3,097 - term infants; GINAplus (German infant study on the influence of nutritional intervention plus environmental and genetic influences on the development of allergies): 5.991 - term infants

Desempenho de escolares com 20 schoolchildren from the 4th to the 8th Schoolchildren with ADHD had a similar performance to that obTranstorno de Déficit de Atenção e grades, 14 boys and 6 girls, aged 9-13 served in the group without behavioral and/or learning disorders Hiperatividade (TDAH) em tarefas years. Gl-10 with ADHD, all of whom metalinguísticas e de leitura(13)

Children with ADHD symptoms are at a greater risk of difficulties in reading/spelling and math when compared to children without ADHD symptoms. The exact functional process and causality pattern underpinning this comorbidity remains unknown. in tasks considered simpler, such as the identification of syllables and phonemes and reading regular words. However, they showed inferior performance in tasks considered more complex, such as the manipulation of syllables and phonemes and the reading of irregular words, which require retention, analysis and retrieval of information. The tests with the poorest performance results were: reading of real words and pseudowords; reading of the grapheme "s" at the end of an internal syllable where it copies the sound feature if the next letter represents a voiced consonant and copies the feature [-son] if it represents a voiceless consonant; reading of the grapheme " $z$ " in the beginning of the word and beginning of the syllable which, before letters representing vowels, is transposed to the realization of the phoneme /z/; rules corresponding to the readings of $\mathrm{I} / \mathrm{j} /$ and $\mathrm{U} / \mathrm{w} /$; referring to three values attributed to the letter " $x$ ", which depend exclusively on the internalization of the orthographic mental lexicon and its relations with the phonological mental lexicon.
Performance lapses in children 67 children, 9 to 14 years of age, 39 with with Attention-Deficit/Hyperactivity $A D H D$ and 28 without.

Disorder contribute to poor reading fluency ${ }^{(12)}$

Children with ADHD had a significantly slower reading fluency in all measures used (GORT-IV reading of texts, WJ-III, TOWRE). After symptom control, the results of non-contextual oral reading fluency remained poor. In comparing reaction times, within the ADHD group, the results showed a correlation between oral contextual fluency, even the severity of the symptoms had been controlled, but did not predict silent or non-contextual oral fluency. The reaction time results were more variable and more distorted when compared to controls.

The role of sustained attention and 20 adolescents aged 15 to 18 years with The ADHD group made more mistakes in reading comprehension. display medium in reading compre- ADHD, 20 without ADHD. The exclusion hension among adolescents with criteria for both groups were having a ADHD and without it ${ }^{(19)}$ diagnosis of neurological disorders other than ADHD, a diagnosis of specific reading and/or language impairment.

Processamento da linguagem no 27 children and adolescents with ADHD, Transtorno de Déficit de Atenção e Hiperatividade (TDAH) ${ }^{(11)}$ tation type, spacing, and sustained attention during reading com-
There was a correlation between reading difficulties and sustained attention. In addition, an interaction was revealed between presenprehension.

Participants with ADHD made mistakes in the word recognition speed (in isolation and in sentences) and inter-sentence coreference processing tests, which revealed subclinical characteristics in the reading processing of this population - this is in turn suggests that those with ADHD have intrinsic reading problems. We have also shown that ADHD patients present with interferences from working memory deficits in language processing, which is actually slower in ADHD patients than in individuals without ADHD. Therefore, the reading speed was reduced and the sentence comprehension was also poorer. 
ARTICLE Disability and Attention-Deficit/Hyperactivity Disorder: Searching for shared cognitive deficits ${ }^{(21)}$
A multiple deficit model of Reading

\section{PARTICIPANTS}

READING PERFORMANCE OUTCOMES

14 boys aged 8 to -16 years: Parents of The processing speed was the only cognitive variable that correall twin pairs aged 8-18 were sought in 22 lated with reading disorder and ADHD, particularly inattention. In local school districts in order to survey addition, the significant correlation between inattention and reading their school records to check for reading was reduced to non-significant when processing speed was incluproblems. If one of the twins had a record ded in the model, thus suggesting that the processing speed conof reading difficulties or met screening cri- tributes to the phenotypic correlation between reading and inattenteria for ADHD, the pair and any other si- tion. This study illustrates the power of a multiple deficit approach blings were asked to participate in the full for comorbidities among neurodevelopmental disorders.

study. A control group for comparing twins was selected from the overall sample of pairs that did not meet the screening criteria for $\mathrm{RD}$ or $\mathrm{ADHD}$. Those having hearing or neurological deficits and an IQ below 70 were excluded.
Desempenho cognitivo-linguístico e 20 students from 5th to 8th grades of priem leitura de escolares com Trans- mary school: 10 with an ADHD (Gl) and 10 torno de Déficit de Atenção e Hipera- without ADHD (GIl) or learning disorders. tividade (TDAH) ${ }^{(10)}$

Gl (with ADHD): poorer phonological awareness results in syllabic and phonemic manipulation abilities, phonemic segmentation, addition, substitution, and syllabic and phonemic combination; poorer reading results - disobeying the rules of univocal regular (D1), or multiple irregular words (D2.3, D2.5, D2.23, and D4), with poorer results when reading irregular and context-dependent word and pseudoword. Therefore, GI (with ADHD) exhibits a change in its performance of activities considered more complex, such as syllabic and phonemic manipulation, not because of a phonological-based language disorder.

Inattention, working memory, and Adolescents aged 13 to 18 years refer- The auditory-verbal working memory showed significant effects academic achievement in adoles- red for ADHD. 73 completed diagnosis in both reading and mathematics. The findings imply that working cents referred for attention deficit/ for ADHD. 37 met subclinical criteria for hyperactivity disorder (ADHD) ${ }^{(18)}$

ADHD (without diagnosis). 29 clinical controls with some ADHD symptoms

memory is a risk factor for school failure in adolescents having attention problems. Working memory influences school performance, but the reading skills involved were not specified.

Comparação do desempenho em 60 literate students: 20 with ADHD (re- Children with ADHD made a greater number of mistakes when sileitura de palavras de crianças com ceiving medication or not) and 40 without lent reading than did the control group. Better performance in phoe sem Transtorno de Déficit de Aten- ADHD. ção e Hiperatividade (TDAH) ${ }^{(9)}$ nological processing tasks than in visual processing tasks, which indicates total mistakes in the reading of pseudowords and a tendency to more pronounced lexicalizations than those found in other participants without ADHD with respect to the activities that involve orthographic processing. Preferred use of the phonological, which characterizes the alphabetic phase of reading. Differences across the responses of all participants were more quantitative than they were qualitative; poorer performance in comparison to the control group.

Figure 3. Sample characterization and results of changes in written language, according to the chronological order of publication

The academic deficits present in ADHD may persist until adult life, even if reduced in severity or the associated symptoms are controlled, as demonstrated in the research of Voigt et al. ${ }^{6}$. The study conducted by Whipple and Nelson ${ }^{7}$, which also included and tracked the performance of adults, showed difficulty in naming tasks in both the ADHD group and the comorbid group. These data are compatible with other findings that report that the incidence rate of ADHD symptoms in adults who showed symptoms in childhood is between 30 and $70 \%$, with the same difficulties persisting in respect of academic performance ${ }^{8}$.

Most of the studies found and analyzed showed that individuals with ADHD had worse academic performance compared to their peers. This data corroborates other studies ${ }^{31}$ that evaluated the academic performance of children without ADHD, with ADHD and, with ADHD and a concomitant learning disorder, and identified performance deficits, especially in reading and writing, both in the ADHD+learning disorder group and in the group with only ADHD ${ }^{20-23}$.

\section{Deficits in phonological and orthographic processing skills}

Among all the studies selected for review, 2 articles showed significant differences between individuals with $A D H D$ and their control group pairs in phonological 
awareness tasks. In one study, the ADHD group with no comorbidity had a worse performance in phonological awareness, and in the other study, only the group with ADHD and with a specific learning disorder as comorbidity had worse performance in phonological awareness compared to the non-ADHD, and ADHD without learning disorder groups.

There was 1 article with a study in respect of orthographic processing in individuals with ADHD. This study reported that individuals with ADHD demonstrated worse performance in rules knowledge and in orthographic memory. None of the participants in the ADHD group had a specific learning disorder as a comorbidity.

Changes in phonological awareness and orthographic rules are often more severe in learning disorders than in ADHD, due to the presence of common phonological and orthographic processing deficits in individuals with reading disorders. Considering that the development of this ability depends on stimulation and correct learning from the preschool stage, it is not uncommon for children with ADHD to present deficits in phonological and orthographic processing as a possible consequence of the presence of ADHD symptoms, such as inattention and impulsivity9,13.

\section{Deficit in Reading performance}

Regarding the analysis of reading performance, the majority of the studies showed that there was a significant difference in performance in reading tasks between children with ADHD and the control group (Table 2). Twenty-one studies (84\%) found that individuals with $A D H D$, with or without reading difficulty as a comorbidity, performed significantly worse in reading tests compared to their non-ADHD peers. The other studies analyzed did not find significant differences in the reading performance of children with ADHD or did not aim to identify the reading profile in this group, although they did examine academic performance.

Tabela 2. Resumo dos estudos por habilidade de leitura investigada

\begin{tabular}{cc}
\hline Related Reading Skills & Number of studies \\
\hline Word reading rate & 9 \\
Word reading accuracy & 9 \\
Pseudoword reading rate & 3 \\
Pseudoword reading rate & 3 \\
Phonological awareness & 2 \\
Comprehension (passage, texts) & 6 \\
Orthographic processing & 3 \\
\hline
\end{tabular}

Of the 21 publications whose results showed poor reading performance in subjects with ADHD, 14 specified different reading-related skills and their characterization in subjects with ADHD. Twelve studies showed a worse performance, specifically in fluency and accuracy of word reading and 3 studies showed worse performance related to pseudoword fluency and accuracy.

The area that showed the greater deficits in the groups with ADHD or groups with a comorbidity (ADHD and learning disabilities) were speed and accuracy of reading ${ }^{6,7,9-17}$. Fluency and reading accuracy are important elements, since they allow monitoring of possible changes in the development of reading ${ }^{32}$. These results are compatible with other studies ${ }^{19}$ that showed reduced speed of reading of words and of non-words in individuals with ADHD.

The understanding of texts, passages, and online comprehension was worse in ADHD groups with or without comorbidity of learning disorder, as shown in six studies ${ }^{9,11,16,20-22}$. The symptoms of individuals with ADHD, such as impulsivity, deficit in inhibitory control, hyperactivity, along with the difficulties in reading present seem to interfere indirectly in reading comprehension, although the etiology of comprehension difficulties in ADHD is not very clear16. This study showed deficits in different aspects of reading comprehension (textual, sentential, inferential) in individuals with ADHD. 


\section{CONCLUSION}

The present study aimed to characterize the reading profile of children with ADHD and identify which abilities are more commonly affected. According to the reviewed literature between 2006 and 2016, these difficulties are present at the phonological level and in orthographic processing, which contribute to difficulties in reading accuracy and fluency, and as a consequence, affect reading comprehension.

\section{REFERENCES}

1. American Psychiatry Association. DSM-V. Diagnostic and Statistical Manual of Mental disorders. 5th.ed. Washington: American Psychiatric Association, 2013.

2. Williams NM, Franke B, Mick E, Anney RJ, Freitag $\mathrm{CM}$, Gill $\mathrm{M}$ et al. Genome-wide analysis of copy number variants in attention deficit hyperactivity disorder: the role of rare variants and duplications at 15q13.3. Am J Psychiatry. 2012;169(2):195-204.

3. Faraone SV, Mick E. Molecular genetics of attention deficit hyperactivity disorder. Psychiatr Clin North Am. 2010;33(1):159-80.

4. Furukawa E, Bado P, Tripp G, Mattos P, Wickens JR, Bramati IE et al. Abnormal striatal bold responses to reward anticipation and reward delivery in ADHD. Plos One. 2014;9(2):e89129.

5. Marx I, Hubner T, Herpertz SC, Berger C, Reuter $\mathrm{E}$, Kircher $\mathrm{T}$ et al. Cross sectional evaluation of cognitive functioning in children, adolescents and young adults with ADHD. J Neural Transm. 2010;117(3):403-29.

6. Voigt RG, Katusic SK, Colligan RC, Killian JM, Weaver AL, Barbaresi WJ. Academic achievement in adults with a history of childhood attentiondeficit/ hyperactivity disorder: a populationbased prospective study. Dev Behav Pediatr. 2016;38(1):1-11.

7. Whipple BD, Nelson JM. Naming speed of adolescents and young adults with attention deficit hyperactivity disorder: differences in alphanumeric versus color/object naming. Archives of Clinical Neuropsychology. 2016;31(1):66-78.

8. Czamara D, Tiesler CMT, Kohlboeck G, Berdel D, Hoffmann B, Bauer CP et al. Children with ADHD symptoms have a higher risk for reading, spelling and math difficulties in the GINIplus and LISAplus cohort studies. PLoS ONE. 2013;8(5):e63859. doi:10.1371/journal.pone.0063859
9. Lobo PAS, Lima LAM. Comparação do desempenho em leitura de palavras de crianças com e sem transtorno de déficit de atenção/ hiperatividade. Rev. CEFAC. 2008;10(4):471-83.

10. Silva C, Cunha VLO, Capellini SA. Desempenho cognitivo-linguístico e em leitura de escolares com Transtorno de Déficit de Atenção e Hiperatividade. Rev Bras. de Cresc. Des. Humano. 2011;21(3):849-58.

11. Albuquerque $G$, Maia $M$, Franca $A$, Mattos $P$, Pastura G. Processamento da linguagem no transtorno do déficit de atenção e hiperatividade (TDAH). D.E.L.T.A. 2012;28(2):245-80.

12. Jacobson LA, Ryan M, Denckla MB, Mostofsky SH, Mahone EM. Performance lapses in children with attention-deficit/hyperactivity disorder contribute to poor reading fluency. Archives of Clinical Neuropsychology. 2013;28(7):672-83.

13. Cunha VLO, Silva C, Lourencetti MD, Padula NAMR, Capellini SA. Performance of students with attention deficit disorder and hyperactivity in metalinguistic and reading tasks. Rev. CEFAC. 2013;15(1):40-50.

14. Stubenrauch C, Freund J, Flers SA, Scharked $W$, Braun $M$, Jacobs AM et al. Nonword reading and Stroop interference: What differentiates attention-deficit/hyperactivity disorder and reading disability? J. of Clinical and Exp. Neuropsych. 2014;36(3):244-60.

15. Sciberras E, Mueller KL, Efron D, Bisset $M$, Anderson V, Schilpzand EJ et al. Language problems in children with ADHD: a communitybased study. Pediatrics. 2014;133(5):793-800.

16. Friedman LM, Rapport MD, Raiker JS, Orban SA, Eckrich SJ. Reading comprehension in boys with ADHD: the mediating roles of working memory and orthographic conversion. J Abnorm Child Psychol. 2016;45(2):273-87.

17. Alves LM, Siqueira CM, Ferreira MCM, Alves JFM, Lodi DF, Bicalho $L$ et al. Rapid naming in brazilian students with dyslexia and attention deficit hyperactivity disorder. Front. Psychol. 2016;7:21. doi: 10.3389/fpsyg.2016.00021

18. Rogers M, Hwang H, Toplak P, Weiss M, Tannock R. Inattention, working memory, and academic achievement in adolescents referred for attention deficit/hyperactivity disorder (ADHD). Child Neuropsychology. 2011;17(5):444-58.

19. Stern $P$, Shalev $L$. The role of sustained attention and display medium in reading comprehension among adolescents with ADHD and without it. 
Res. Dev. Disab.: A Multidisciplinary Journal. 2013;34(1):431-9.

20. Yeari M, Avramovich A, Schiff R. Online inferential and textual processing by adolescents with attention-deficit/hyperactivity disorder during reading comprehension: evidence from a probing method. J. of Clinical and Exp. Neuropsych. 2016;39(5):1-17.

21. McGrath LM, Pennington BF, Shanahan MA, Santerre-Lemmon LE, Barnard HD, Willcutt EG et al. A multiple deficit model of reading disability and attention-deficit/hyperactivity disorder: searching for shared cognitive deficits. J Child Psychol Psychiatry. 2011;52(5):547-57. Doi:10.1111/j.1469-7610.2010.02346.x.

22. DuPaul GJ, Morgan PL, Farkas G, Hillemeier MM, Maczuga S. Academic and social functioning associated with attention-deficit/hyperactivity disorder: latent class analyses of trajectories from kindergarten to fifth grade. Journal of Abnormal Child Psychology. 2016;44(7):1425-38.

23. Efron D, Sciberras E, Anderson V, Hazell $P$, Ukoumunne OC, Jongeling $B$ et al. Functional status in children With ADHD at age 6;8: a controlled community. Pediatrics. 2014;134(4):e992-e1000.

24. Kibby MY, Dyer SM, Vadnais SA, Jagger AC, Casher GA, Stacy M. Visual processing in reading disorders and attention-deficit/hyperactivity disorder and its contribution to basic reading ability. Front. Psychol. 2015;6:1635. doi: 10.3389/fpsyg.2015.01635

25. Martinussen R, Mackenzie G. Reading comprehension in adolescents with ADHD: exploring the poor comprehender profile and individual differences in vocabulary and executive functions. Research in Dev. Disab. 2015;38:329-37.

26. Miranda A, Colomer C, Mercader J, Fernández M, Presentación MJ. Performance-based tests versus behavioral ratings in the assessment of executive functioning in preschoolers: associations with ADHD symptoms and reading achievement. Front. Psychol. 2015;6:545. doi: 10.3389/ fpsyg.2015.00545

27. Owens J, Jackson H. Attention-deficit/ hyperactivity disorder severity, diagnosis, \& later academic achievement in a national sample. Soc Sci Res. 2016;61:251-65. doi: 10.1016/j. ssresearch.2016.06.018

28. Rennie B, Beebe-Frankenberger M, Swanson HL. A longitudinal study of neuropsychological functioning and academic achievement in children with and without signs of attention deficit/hyperactivity disorder. $J$ of Clinical and Exp Neuropsychology. 2014;36(6):621-35. DOI: 10.1080/13803395.2014.921284

29. Tamm I, Epstein JN, Denton CA, Vaughn AJ, Peugh J, Willcutt EG. Reaction time variability associated with reading skills in poor readers with ADHD. J Int Neuropsychol Soc. 2014;20(3):292-301. doi:10.1017/ S1355617713001495

30. Van de Voorde S, Roeyers H, Verté S, Wiersema JR. The influence of working memory load on response inhibition in children with attentiondeficit/hyperactivity disorder or reading disorder. $J$ of Clinical and Exp Neuropsychology. 2014;33(7):753-64.

31. Willcutt E, Pennington B, Olson R, Chhabildas $\mathrm{N}$, Hulslander J. Neuropsychological analyses of comorbidity between reading disability and attention deficit hyperactivity disorder: in search of the common deficit. Dev. Neuropsych. 2005;27(1):35-78.

32. Francis DJ, Santi KL, Barr C, Fletcher JM, Varisco A, Foorman BR. Form effects on the estimation of students' oral reading fluency using DIBELS. J School Psychol. 2008;46(3):315-42. 